\title{
Mobility and Literacy: Development of the Public Network Concept
}

\author{
KEDRICK JAMES \\ University of British Columbia
}

\begin{abstract}
This paper briefly historicizes English language mail services, postal reform, and the inauguration of global delivery systems for material mails in order to outline the origins of junk mail and discursive excess in network concepts and systems. These historical developments not only made mail services affordable to common people, but also created the conditions necessary for inexpensive, rapid delivery---and dumping---of bulk advertising and circulars (the precursor of spam email) throughout the literate field of personal correspondences. From a contemporary perspective, electronic mail alters conventions that have evolved through epistolary practices. Situated on a background of a formal, dialogical ethos of personal answerability among a distributed public, mass mail makes global populations the object rather than a dialogical subject of literate relations, with consequential changes to social and cultural habits and attitudes toward personal correspondence. To conclude this paper explores global dynamics of digital correspondence that place unanswerability at the core of twenty-first century dialogical relations.
\end{abstract}

\section{Introduction}

The mobility of written, dialogical correspondence inspires, transforms, and continues to shape contemporary literacy practices. This paper surveys a series of trends in public correspondence networks of Britain and America from the seventeenth to the twentieth centuries. These trends have remained constant through the present day, even in the wake of the widespread transformation to electronic networks which has been accompanied by seemingly endless innovation in the field of communications technologies. The most significant, enigmatic, and problematic area of concern for this study lies in the complex and changing relationship of situated persons to their autonomous mobile networks, as well as the physical systems and conceptual frameworks by which they interact and through which interpersonal correspondence is conducted.

Communications networks not only transmit but also help to shape discourse, formally constraining participation by the entities they network. In order to outline these formal constrains and their influence upon users, we might ask a number of questions of the contemporary network concept: What characteristics do writers, readers, and even messengers have in common? What socio-cultural conventions and laws should they uphold? To what degree is the network, an agent in these relations, able to withhold its services or use those services for other purposes? To answer these questions we must also raise others. Should the network be sovereign, public, privately owned or distributed? Is being in the network the same as being situated in a literacy environment? Finally, and perhaps most importantly, to what extent does the network environment reflect and inform the mores of the literate society it encompasses? Such questions interrogate the 
ethical basis of mobile literacies and the underlying principles of exchange in any literacy "transactions" (Rosenblatt, 2004, p. 1363) that occur at a distance. To push this line of questioning a little further, to what degree are these entities---the correspondents in networked transactions---known to and responsible for each other's well being? Or, to rephrase this last question in a way germane to Bakhtin's ethical philosophy, to what degree are the network entities responsible on the grounds of being answerable to one another (Bakhtin, 1990; Nielsen, 2002; Tate, 1994)?

It is not possible within the scope of this paper to answer all these questions, and by focusing on the last two I provide a cautionary rather than celebratory viewpoint. The communications network concept of today is becoming interiorized: Networked technologies are in bedrooms, being worn on the body like jewelry, and, soon or later with recent developments in nanotechnology, may well be installed in the body. No more will network "media [be] extensions of some human faculty---psychic or physical" in space, as McLuhan, Fiore, and Agel (1967) suggest, but rather the inverse: extensions of some network faculty into the space of our bodies, a reversal of the once-basic ontological characteristics of literate correspondence. Pos(i)ting the self as the site of public spectacle is a familiar feature of social media even now. Such a vision of the postperson's writing self---a network entity, a radically distributed self that has lost integrity and become a media network cipher---is becoming readily apparent in Western society. Through public trial and error, then, is contemporary Western society examining the dangers of constant interaction with mobile communications networks. The following essay reflects on a number of historical trends over the development of the contemporary network concept. The common theme through these explorations is that mail systems, undergirded by a network concept, are implicated in the conditions of our literacy environments and the kind of ethical understandings that are harboured therein.

\section{Postal Origins of the Contemporary Network Concept}

With almost two billion email users worldwide staging the largest migration in person-to-person networked writing practices, the mid-nineteenth century postal reforms and the creation of the World Postal Union have been eclipsed as the most momentous events in the history of public correspondence. It is too early for a post-mortem on the post office, but a prescient overview of the evolution of the network concept underlying mobile literacy might contextualize the phenomenal presence of email in everyday literacy practices. Moreover, new social media networks are increasingly used for the posting of personal messages, and for those millions of people worldwide who have sufficient access to online networks, the post office is quickly becoming a relic of literacy's past.

Handwritten letters have in large part followed the destiny of the post office. Personally, I have not sent or received handwritten letters through the mail in a roughly a decade, around the same time literacy theorists Barton and Hall (2000) edited Letter Writing As A Social Practice, a book which builds upon the study of literacy as situated in its specific environment and positions letter writing as a pervasive social practice of literacy with a deep and complex history. Notably, the collection contains only the one final chapter on "Computer mediated communication: The future of the letter?" (Yates, 2000). This chapter was posed as a question, a question that has been answered quite emphatically in the intervening years. 
Bernhard Siegert's Relays: Literature as an Epoch of the Postal System (1999), originally published in 1993 (the same year that Tim Berners-Lee launched the World Wide Web [IDC, 2007]), critiques the materiality and situated ethos of the writing self during the rise of widespread epistolary practices in Europe between 1750 and 1920, and the formal, dialogical personhood conferred upon users through postal systems. The network concept is fundamental to the discussion of mobility and literacy, as Hall (2000) might agree when he writes that there was "relatively free choice" for letter writers up to "the point of sticking on a stamp [when] the process changes and the letter writer becomes subject to bureaucracy and law" (p. 102). At this same moment, the writing self becomes a subject of the state---in one sense a citizen exercising civil behaviours and rights, and in another sense a consumer, paying for a network service. Follow this transition to the present day: Literacy, in all its modalities, has become the prime commodity of a consumptive network concept into which our mobilized lives flow. The network, rather than the addressee, is the moral, legal, monetizing, proprietary, and stabilized, situated, generative, sacrosanct Other. It and we have traded ontological positions. Some scholars have argued that the right to privacy and the bonds of personhood are not only no longer guaranteed, but are perhaps now a threat to, and even by, the network (Capurro, 2006; Dahlberg, 2001; Locke, 1998).

To untangle these questions and cast into the future of mobile literacy, we are well advised by Poster (1990), and later by Henkin (2006), to remember that "despite all the changes that separate us from the postal culture of the mid-nineteenth century... the world we now inhabit belongs to the extended history of that moment" (p. 175). That moment not only made mail affordable to common people, but also created the conditions necessary for inexpensive, rapid delivery of bulk advertising and circulars into personal correspondence. Political and technical developments of postal systems bore the personhood of literate communicators as a symbol of civic distinction (see Bourdieu, 1984, in the context of social and cultural capital) through complex transactions of linguistic capital (Prinsloo, 2005). Closely connected to these trends, mass mailing arose as a countervailing tendency that eventually undermined the sovereignty of the network. The ensuing developments in the network concept increasingly included the personally addressed impersonal letter---or junk mail (Henkin, 2006, pp. 146-158)---at which point the sovereignty of postal subjects became the mass market of literate consumers.

Once the letter, a folded and sealed personal world, is submitted to public systems of the post, both the text and the author become the technologically-mediated subjects of the network. The letter was once regarded as serving in the place of an absent person: "It was, " Seigert (1999) emphasizes, "what it transmitted---an individual, that is, and could therefore answer for that individual" (p. 28). However, transposition of the network concept during the mid-nineteenth century, first through mechanization and later through automation, set the stage for imposters and impersonators. These unanswerable proxies for answerable individuals in the forms of bulk mail became (and continue to be) overbearing on space and attention in the carriages of public correspondence (Noam, 1987). What the network of literate correspondences once gave---the possibility of intimate, personal contact over a distance---it now takes away, replacing what Siegert romantically calls the "poet's dream of unfettered communication" with the anonymous mass-market ethos of literacy-as-consumerism and knowledge-as-proprietary-information 
(Beebee, 2003, p. 329). Beneath appearances, all data is hidden, encoded in digital transit---easily alienated, easily dispelled into absence.

As soon as the postal organization formed according to a business model, the letter-writing self---as an individual networking among the literate citizenry--experienced the rupture of the network relay, the break with personal values, the effacement of authorship, and the vanishing record of intimate discourses (Siegert, 1999). These changes involved shifts in network consciousness coupled with innovations in literacy technologies and postal transport capacities. Mobilizing the literacy practices of mid-nineteenth century, Great Britain and antebellum America also mobilized commercialization, automation, and disposability of the mails in an unprecedented manner. While pale in comparison to the deluge of microwave data today, these processes and inventions paved the way to present-day literate personhood. This path began in the late eighteenth century, opened by the many technological changes during the Industrial Revolution.

We should not underestimate the level of common enthusiasm for literate correspondence in the intervening post-Reformation period of the Enlightenment that led up to Britain's mid-nineteenth century postal reforms. The industrial revolution triggered rapid urbanization and the mass production of, among other things, newspapers, journals and books, making them more affordable to those with a modest income (Fuller, 2003). The middle classes educated their children in literacy and numeracy, and, as a result, bookstores proliferated. Book trade expanded at a time when reading for entertainment, not just administration or edification, became prevalent. Some popular themes in novels of the day reveal this trend. One of the first novels to celebrate the romance and intrigue of epistolary communication was Charles Gildon's book The Post-Man Robb'd of his Mail or the Packet Broke Open, published in 1719, which enjoyed almost immediate popularity (Bosse, 1972). The premise of the narrative is the discovery, by a couple of traveling gentry, of a postman's mail bags that had been discarded by his (presumably illiterate) attackers. The mail bags were then carried to a country manor whereupon the letters were opened and copied before being forwarded through family networks to their respective destinations. Gildon uses the divulging of the contents of the mail as a literary device for exposing and critiquing the inner workings of the social order that was instituted through the Royal Post's network. The author moralizes on the contents of the copied and published letters as if they were real correspondences. Interestingly, he foreshadows key features of mass postal culture and the psychology of the written self, expressing the vulnerability of written correspondence to fraudulent misappropriation, misinformation, plagiarism, and exposure of private matters in the public domain. As a venue of intimacy subject to "media logics," the subjectivity of the publics' correspondence networks mapped a new discursive terrain of "the technical protocols of interiority" (Seltzer, 2000, p. 197). ${ }^{\mathrm{i}}$

\section{The Eighteenth Century Construction of Epistolary Subjectivity}

The interior consciousness that was being shaped by technical protocols of the public post in the eighteenth century involved navigating the intimacies of love as much as conducting news. Siegert (1999) argues that Goethe inaugurated, while Kafka presided over the end of, literature as an epoch of the postal system, a time during which the interiority of the writing self was being mapped through correspondence practices that 
treated the letter itself as an object of devotion. The letter was chaste, a sealed world, an intimate relation. The media logics of new postal network technologies and protocols both mechanized and chaperoned the romance associated with writing. Novels of the eighteenth century were not necessarily concerned with intervention in society's values; more commonly, writers conjured pulp-fiction themes of illicit love, sure to find a ready audience. Among those who sought to edify the popular novel was Samuel Richardson, a successor to Gildon, whose epistolary novels Pamela and Clarissa were best sellers (Sale, 1950). Richardson, who ran a successful publishing business, was astute about the new reading public and recognized that women in particular were commonly written off as flat, stereotypic characters restricted to their domestic duties and confines, even though they made up a large portion of the newly literate readership (Cook, 1996). In Pamela, or Virtue Rewarded, the epistolary form gave Richardson (1740) an ability to bring to light a domestic narrative without identifying himself with it, and to posit a heroine whose morality stood the test of male advance and aggression. ${ }^{\text {ii }}$ Combining moral and commercial interests through the epistolary narrative form, Richardson presaged the reformist agenda manifest in the public post a century later (Shuttleton, 1999).

The popularization of correspondences as a form of literature created a perception of the mails as the provocative parade through a public space of the private lives of individuals, and this domesticated the contents of literate communications in a way that had hitherto not been the primary function (Siegert, 1999). The post had historically been a form of public address carried out at a distance involving many intermediaries; letters were commonly meant to introduce the messenger, and messages were delivered orally, thereby assuring a reply. Literature personalized correspondence and fomented the gendering of the letter the contents of which---concealed within folds and sealed for privacy---became symbolic of private desire and domestic agency discretely conducted through a public space (Armstrong, 1987).

Expression of personal worlds through the public context of the post (where the post can be understood as privately publishing the writing self) engages the reader in an unfolding, exploring, and constructing of another's world that not only influenced writing practices of the past, but reading practices as well. The reader as personal addressee takes a formative presence within the text; the text coheres through the sovereignty of the dialogical relationship. Dierks (2000), assessing the letter-writing manuals of eighteenth century America (which he asserts were largely formulated on similar British publications), states that "every aspect of quotidian life stood available to build an emotional connection between letter writer and letter reader, as long as it served to affirm the depth of personal attachment between the two" (p. 35). Letters formalized answerability while casting the certainty of presence, of response, into doubt. A letter might never arrive, becoming the lost property of the public network, and, thus, exempt from emblematic sovereignty. Moreover, the individual writer was represented in the letter's contents as a psychological entity to be reconstructed from within the text.

The textual psychology of the writing subject was even placed in humorous relief in Laurence Sterne's novel Tristram Shandy. Sterne was Richardson's contemporary, and where Pamela and Clarissa brings to light the technological form of the letter and its role in private affairs, Sterne's ranging missives---the chaotic thoughts of Shandy's inner world---are constructed into a relational whole by a reader who is the complicit co-author of the thoughts, rather than an explicit addressee. Sterne's novel evokes the psychological 
significance of the letter without postal intermediation. Today, Tristram Shandy offers cultural theorists an intriguing precursor of hypertext, in which reader and writer coauthor a multi-sequential text (Aareseth, 1997; Allen, 2003; Landow, 1997). As Yellowlees Douglas (2001) states:

Mimicking the epistolary novels of his era that were directed toward a reading subject (who was not, however, the 'real' reader but a character within the fiction itself), Tristram directly addresses his surrogate reading public, but in the form of a ridiculous construction---a slightly stuffy female reader. (p. 22)

Taken together, the popularity of Sterne's and Richardson's novels was founded on the contemporary literate worldview that was being shaped through changing conceptions of the mails as a virtu(e)al space of and for the writing self.

The spontaneous, disjointed narrative style explored by Sterne, taken in conjunction with the adroit, moral and civilizing tone in Richardson, underline the transforming presence of the network concept among European and American middle classes and their pedagogies of literacy. In "The Familiar Letter and Social Refinement in America," Dierk emphasizes that pedagogical directives of eighteenth-century letter writing manuals in America sought "an elusive middle ground" in letter-writing style; "the ideal style for a familiar letter," he comments, "was an appearance of spontaneous ease, even where tremendous care is taken" (2000, pp. 35-36). Given the "persistent belief that one's writing style reflected one's social position," the goal was to "straddle the conversational and the correct, the artless and the disciplined" Dierk continues: "familiar letters licensed people to write in an emotional and conversational style, at the same time they warned against desultory incoherence. Familiar letters were meant to be spontaneous but certainly not disjointed" (p. 35) hence the humour of Shandy's inner monologue and the familiar tension it demonstrates. This challenging task of writing formally (in honour of the network) while speaking from the heart (in the presence of friends) underscores the societal conflicts within the evolving network concept of the day. The network was a mobilizing force requiring formal observances, while facilitating its users engaging in personal, internalized conversation with the intimate other, with both acts enshrined in the literacy practice of personal letter writing. It was a skill that, according to the manual publishers, required months of "constant attention" to learn (and, of course, a manual).

Through popular literature, schooling, and manuals, the way was paved for a postal reform in the later nineteenth century. Popularization and personalization of correspondence-practices within middle class cultures created a vent for domestic and intimate matters via channels of public correspondence. The symbolic significance of letter writing as a measure of social status, educated cultivation, as well as participatory, literate citizenship, added ideological force to postal reform and the extension of mail services to rural populations and poor urban districts through affordable postage and infrastructural expansion (Boureau \& Dauphin, 1997).

\section{Mid-Nineteenth Century Reform of the Post from Royal Mail to Public Service}

In 1860, one hundred years before the first electronic message was left on a shared computer in the MIT lab, Queen Victoria knighted Rowland Hill for his reforms of the British postal system, reforms which allowed for an efficiently organized, public 
postal system to take root. Daunton (1985) explains that until Hill's several reforms as Secretary of the Post---which included the nationalizing of the penny post, development of the prepaid, gum-backed, paper stamp, amalgamation of independent coach and carrier services, inauguration of the post box, and systematization of London postal districts--the General Post was overpriced and limited in scope to postal routes and roads in and between large municipalities. There were no delivery services per se, except in elite Westminster and between diplomats, government officials, or royal senders.

Before these reforms, postage had been too expensive for most 'commoners' and the lack of services in rural and poorer urban districts acted, as Hill and others foresaw, as a deterrent to increasing the postal monopoly's revenue, with the added effect of demotivating the working classes and poor from overcoming varying degrees of illiteracy and becoming educated. The ancillary social advantages of a literate, letter-writing population gave political urgency to mail reform, although in the end a fiscal agenda determined its progress (Daunton, 1985; Kielbowicz, 1989). Business also stood to benefit from the reforms, as businesses had become primary payees of the Royal letter post. The coupling of a moralistic, social agency that underscored the government postal monopoly with the competitive, capitalistic ideology that underwrote the implementation of a new postal policy propelled the global expansion of postal services and epistolary practices into all walks of life (Fuller, 2003; Henkin, 2006; Kielbowicz, 2007; Lyons, 1999), However, it also supplied the conditions for its post-WWII and continuing decline (Campbell, 2002). Today, physical mail is but a cultural shadow of its once highly prominent position within personal, national and international affairs (Hôflich \& Gebhardt, 2005; Krug, 2005).

In England, the Reform Bill of 1830 enfranchised a new electorate of wealthy middle class citizens who dogmatically favored a laissez-faire, free-market ideology, self-reliance, economic thrift, and "pull yourself up by the bootstraps" ambition (Daunton, 1985). Hill applied this ideology to both education and the mails (Siegert, 1999). The continuing industrial revolution had destabilized the closed systems of aristocratic title and privilege that acted as a barrier to self-motivated social advancement. Among the burgeoning middle classes, competition was favored over nepotism, and reformers regarded many of the old public systems and institutions as up for grabs. Hill's first reformist experiment was Hill Top School, a school established by his father. As Daunton (1985) explains:

The school was a family enterprise in which the brothers became teachers in their early teens, and it was Matthew and Roland who were to transform Thomas Wright Hill's conventional institution into an educational experiment which appealed to the competitive business spirit of the early nineteenth-century Britain and attracted national attention. They were, in short, educational entrepreneurs. (p. 12)

The Hill's published their pedagogical method, the Hazelwood System, in an anonymous pamphlet titled Public Education (printed in 1822) and brought a copy to the utilitarian philosopher Jeremy Bentham, securing his patronage of their school. The Hills opened two other schools before centering their operations in London, where Rowland became intent on reforming other aspects of the political system. He authored pamphlets to express these desires, but it was not until the publication of Post Office Reform (1837), 
where he outlined his plan for reforming the mails, that Hill began to directly influence political structures of the day.

Moreover, the reform of the Royal Post promulgated a much broader vision of mail services: the general public entered the scholarly domain of literae humanoires, while commercial interests gained access to systems of the post and education (Siegert, 1999). The general public changed from a civil mass to a network of linked individuals capable of sending and receiving correspondence. These accomplishments occurred only in relation to changes in writing and transportation technologies and the eventual reconfiguration of the physical post within the newly available telecommunications network-concept (Noam, 1987). The greatest and longest lasting reform credited to Rowland Hill was the uniform penny post. Hill (1837) wrote that postal reform "would bring immediate, substantial, practical, indisputable relief to all" (p. 68). The 1840 advent of the international penny post was met with high demand (Daunton, 1985): within a decade, stamps had been adopted by Brazil, Switzerland, the United States, Mauritius, France, Belgium, and Bavaria. Once Britain allowed her extensive colonies to issue their own stamps, international mail service became global in scope. In 1874, the first congress of the World Postal Union (later the Union Postale Universelle, a United Nations affiliated NGO) convened in Switzerland as an intergovernmental organization committed to the social, cultural and commercial communications among all people (Campbell, 2002; Universal Postal Union, 2003). It established a flat rate of postage between its member nations whose ranks expanded to include all of Europe, Russia, Persia, Japan, Turkey, and so forth, regardless of their bilateral relations. This was to remain in effect until the WWI, when programs of national censorship began (Boyer, 2002; Price, 1942).

Technological change came in many different forms: Cheap postage, cheap paper, prepaid stamps, international postal infrastructures, and significantly improved transportation. The shift from mail coach to rail transport, though, ushered in an era of rapid delivery that made the writing of personal correspondence a daily event in the lives of many people around the world (Krug, 2005). Epistolary form brought a welcome intimacy to literacy in which the personal lives of correspondents could be sealed and disclosed in private regardless of their physical separation; this practice is described by Milne (2003) as the first virtual community's "dance between absence and presence" ( $p$. 3 ). Business government agencies, publishing houses and commercial trade supplied the bulk of all letter mail until the mid-eighteenth century, ${ }^{\text {iii }}$ cheap postage and regionalized services brought about a boom in the personal letter business (Daunton, 1985). Many national postal organizations used letter revenues to support competitive or monopolistic forays into the parcel delivery, financial services and, eventually, telecommunications. As Campbell (2002) states, "most countries that have reformed their Posts have felt the need to liberalize their postal markets to some degree, as a way of realigning their Posts to technological change and globalization" (p. 5). The institution of the post office rose in prominence both in government affairs and as a point of popular contact with the world at large. In this way, public education and the public post mutually redefined citizenship: The rapid rise in literacy rates brought about by trade unions and fellowship halls, dame schools, Sunday schools, and charity schools created the conditions for a popular postal culture to flourish. In light of the success of postal reform (once a literate public could be 
shown to bring economic and social benefit to the nation), it was politically prescient to institute nationalized public education.

However, numerous mobility challenges to the infrastructural development of a public postal service lay ahead. Two desirable sets of features, speed and reliability, volume and delivery, were contradictory problems facing postal reform; on the one hand a problem of how to move masses of mail rapidly and on the other hand how to individually track, relay, and deliver items in the mail stream. Formalizing modes of address into a universal system of codes and destinations was a large part of the solution. A worldwide postal service required a worldwide register of resident populations. Personal mobility, enhanced through the same technologies that improved transport of the mails, posed significant challenges to such universal postal organization. Post offices had to contend with problems of persons having no fixed address, wrongly addressed letters, fraudulent use of the system, or even the death of correspondents.

The implications of lost messages, given the enormous personal significance that had been ascribed to literate correspondence, loomed in the imagination of networked correspondents. The same system that formed the communicative bond could also cause it to falter and break, and in this way the postal relay, like biblical Babel, not only reflected a cohering network, but also a diaspora of communication---an absence into which all hearts opened and all lines flowed. As Derrida (1978) writes regarding the psychoanalytic aspects of the postal concept in Poe's The Purloined Letter, "a letter does not always arrive at its destination, and from the moment that this possibility belongs to its structure one can say that it never truly arrives, that when it does arrive its capacity not to arrive torments it with an internal drifting" (p. 123). For Derrida, letters contain a phenomenological absence that is not overcome by reception but remains integral to the written text submitted to the physical, or for that matter metaphysical, post.

In the process of becoming a venue of intimate expression of the writing self, the mail formed a public environment for personal values to be mapped upon the interiority of the network. The mid-nineteenth century postal reforms expanded the network concept to serve as a market place, introducing values that are anathema to the educational, sublime, promissory values embedded in formalized social codes of literate exchange (Milne, 2002; Veidemanis, 1982). Before the onset of market and media logistics, the epistolary construction of the writing self, situated within a literary-postal network concept, adopted "the logistics of the poet's dream" (Siegert, 1999, pp. 84-91) in which a love affair with language and the products of literacy enact a consummating expression--in high contrast to audiencing social or mass media (Cubitt, 2005). The technological and ideological reconstruction of postal services contributed to de-personalizing the network concept through a number of mechanizations that extended from the means of writing (mechanical typewriter), of publishing (rotary press), and of transportation (rail and motor). Mass mail turned the personhood of the writing self into a systemic variable, a cipher of destination, leading eventually to the information age of the late twentieth century (Himma, 2007). Reciprocity of communication was no longer assured; all forms of difference that had enhanced uniqueness of the correspondence-event in the poet's "dream logic" now interrupted the regular flow of discourse in the network. Literature of the postal epoch would eventually find itself reduced to the state of its transmission. 


\section{Commercial Interests in Postal Networks}

The desire for competitive advantage in international trade relations put a high priority on the postal service as a source of news and newspapers. By the mid-to-latenineteenth century, the bulk of newsprint had overtaken the volume of mails transported by the post offices of England and America (Daunton, 1985; John, 1995; Kielbowicz, 1989). And thus, another change in the postal network concept was underway, insofar as the post was seen as a bearer of public information as much as of private correspondences. This was particularly the case for the United States Postal Service with its widely distributed populations, many of them quite remote and entirely reliant on transportation of newspapers for contact with the external world (John, 1995). The private carriage of mails was not inhibited by state interests as it had been in Europe, and private enterprise in the delivery of mails thrived until the mid-nineteenth century consolidation of the U. S. Postal Service and the creation of the Railway Postal Service that could move large volumes of mail at little extra expense to the carrier. Post offices in America not only spread news but also gave access to goods and literature of various sorts otherwise locally unavailable. Once it had become an inexpensive mode of transporting all printed matter, it also became a means of marketing and commercial solicitation of the public.

The increased speed and capacity of postal railway networks spread a wide variety of texts across great distances and this coursing of potentially dangerous or offensive literature through the body politic of nineteenth century America inspired moral panic. Religious groups opposed the delivery of mail on the Sabbath day and organized vigilante attempts and political encouragements for state intervention in and censorship of the content of the mails (Fuller, 2003). The postal system was seen as conveying aesthetic and moral values conferred through literacy, and regulation was deemed necessary (see also John, 1995; Kielbowicz, 2007). Shortly after the British postal reforms, the individual right to affordable correspondence in America was advocated for and granted. However, the postal network rapidly became a means of gaining as much as giving public access; mass unsolicited correspondence gained access to the private home and hearth as a venue for advertising, a venue that the commodity culture had previously been denied. A moral crisis was brought on by mail reform. Mails that had served as the discursive life-force of the body politic could spread bad content---immoral literature---like a contagion, a literacy virus. Religious groups argued that commercial mail would spiritually pollute the nation. To rid the system of this bad blood, moral filtering of the mail had to be implemented at the site of sorting the mail, a dynamic on-track process during relay, rather than at a post station. This surveillance and regulatory initiative instantiated a network concept that ought to monitor and oversee the individuals it served; such a perusal of mobile literacy practices presages the privacy issues that have become a hot topic in electronic network mail services today.

\section{Junk, Spam, and Other Transients}

Because the classification of bulk (unsealed) mail was so vague, mail circulars were sent at the newspaper-periodical postage rate which, cheap as it was, often went unpaid. "On much of this kind of matter sent in the mails," the postmaster general complained in 1855, "no postage at all is collected. The greatest abuse in this respect pertains to lottery and patent medicine circulars and pamphlets with which the mails in every part of the 
country are burdened. In some instances from thirty to forty bags of this matter have been received in one day for distribution at a single office" (quoted in Fuller, 2003, p. 163). ${ }^{\text {iv }}$ Of the many mass publications that freeloaded on the public mail service, mail circulars are of particular interest in the study of a communications network ethos. Many were bulk mail swindles, attempting to defraud the large number of people new to the mails and unaccustomed to distrusting the authority and validity of written communications:

Already by mid-century, many Americans (principally those in cities) inhabited a world full of paper detritus. Posted circulars may have been addressed to individuals (unlike the posters and broadsides that littered city streets), but they still epitomized the impersonal communication associated with modern print culture. (Henkin, 2006, p. 155)

Like the senders of spam email, authors of circulars harvested personal addresses from a wide variety of textual resources; ironically, the most useful resources of all were publications by the post office in daily newspapers listing the names and addresses on letters that remained unclaimed or undeliverable, and were therefore destined for the Dead Letter Office. The rapid expansion of mail networks and cheap rates provided the right conditions for impersonal mail to become big business. All that was required was the formal point of address and a scriptorium to imitate the confidences of private correspondence, and circular senders had hundreds of thousands of names at their disposal:

While names (and therefore addresses) were publicly accessible for these early purveyors of spam, victims of circular swindles received letters that often appeared quite private, addressed to them as individuals and pitched discreetly under the protective seal of wafer, gum, or envelope .... these operations exploited and underscored the massive scale of the postal network, which allowed swindlers to cast an exceptionally wide net and at minimal expense. Even a small percentage of replies from eager victims remitting a dollar or just a postage stamp could transform into a major windfall. (Henkin, 2006, p. 193)

Advertising and marketing held a captive and credulous domestic market. What was public in nature could now enter intimate space, and simultaneously, intimacy became a public spectacle of the new postal culture that had come into existence.

This voyeuristic appeal of the public spectacle of the private letter was nowhere more apparent than in the Dead Letter Office instituted by America's first postmaster general, Benjamin Franklin, in Washington, DC. In the Dead Letter Office, the public could peruse mail "accumulated in unsurpassed volumes and systematically pried open" (Henkin, 2006, p. 160), thus revealing the intimate lives not only of people from around the world, but the intimate life of the post itself, a fictive and fantastic commonplace of the public at large. The visible display of tens of thousands of actual letters, misnamed, wrongly addressed, perhaps sent to persons no longer alive, and containing all manner of personal effects (locks of hair, trinkets, money, lipstick kisses on paper, poems and pictures, and so forth), the traces of misplaced lives, unrequited loves, and concerns or proposals whose answers were never forthcoming, gave the postal culture of the 
nineteenth century a mystique that captured the public's imagination. The fate of the letter spoke of the fate of individuals, a connection it inherited from antebellum times. The Dead Letter Office allowed the public to peer inside the literate workings of the spectacle of a society liberated by mail and yet divided by the density of their discourse and the destiny of their disclosure.

Postal services that had historically ordered and defined the realms of personhood and public citizenship by plotting the relational paths of discourse geographically were now confronted with a paradox of mobility. If the correspondents are not places on a map but are themselves mobile, then the sovereign pledge of the system to deliver the mail is in jeopardy. Increases to the mobility of the mails reflected increases to the mobility of the greater mass of human populations. By the end of the nineteenth century, the network concept had become highly visible: post offices and their numerous, uniformed postal employees were a common site (Cooke, 2007) and home delivery was becoming an expected, even necessary, ingredient of middle-class life.

But postal times were a' changing. Even by the mid 1870s "the great majority of the mail arriving at post offices was posted to parties whom the sender did not know" (Henkin, 2006, p. 169). Although this had also been true of newsprint and governmentfranked mail, Henkin (2006) continues:

After the mid-century reforms, the privilege became democratized, at least to the extent that the power to communicate with many unknown persons was available to anyone who could afford printing costs (or the burden of extensive copying) and radically reduced postal rates. A wide assortment of publishers, ideologues, schemers, fund-raisers, pranksters, entrepreneurs, solicitors, marriage-seekers, and others flooded the mails with the sort of correspondence that simultaneously exploited and eroded popular notions of the letter as a form of personal relationship across distance. (p. 169)

In the wake of unprecedented volumes of mail and impersonal informational excess, literate culture became more and more burdened and, finding itself overwhelmed, new practices arose as means of coping and self-preserving. The need to regulate the flow of information and selectively suppress personal solicitation arising within the network became a serious concern through the mid-to-late nineteenth century (Spinello, 1999, 2001), and this need implicated coeval literacy practices.

\section{Paper Waste and Communicable Disease}

The literate culture of network correspondences, as a treasury of formalized intimacies, has undergone radical change---first through the erosion of the authorial sovereignty in relation to discrete addressees, and second through a related transfer of originality to networks that attain productive and discriminating agency, but an agency that is not itself answerable to or for its role in shaping public or personal discourses. Left without an answerable set of circumstances, the subject is cut adrift from responsive agency but for one option---to delete.

The mass production of mail contributed to conditions in which the recipient of communications was relegated to a faceless uniformity in an information network. This may explain the current popularity of social media such as Facebook, where selfrepresentation of personhood and familiarity is integrated into formal design features of 
the network; thus facilitating conditions of answerability that broadcast media networks, also by design, tend to deny. Yet we remain confronted with anonymity and absence of any substantive personhood truthfully revealed, thereby mimicking the nineteenthcentury messages of postal circulars making their rounds. Henkin (2006) relates that circular schemes were so flawlessly executed that "an inexperienced addressee might easily imagine...that he was reading a letter prepared for him exclusively" (p. 167). The impersonal yet personal "you" to whom the schemers wrote carries singular and plural connotations, a familiar yet simultaneously open letter. "You" is a generic consumer of information, no longer a subject but an object of discourse. The commercial interests of parasitic circulars had found a healthy host in a public that had been opened up to a profound means of discursive authority and sincerity, a textual gift-economy of personal literate exchange.

A side effect of postal reforms and new transportation technologies was the subsequent boom in several industries related to the technologies of writing, to paper in particular. In Europe and America in the early 1800s, paper had been primarily made out of rags, beaten, dissolved into independent fibers using lime and then screened into sheets. The addition of cellulose from straw made newsprint cheaper. Paper was expensive and so very little disposable paper (in the form of cups, plates, napkins, or even toilet paper) was in existence; outdated newsprint served a wide variety of commercial and domestic reuses, providing much needed packaging, cleaning, lining, and stuffing materials. As Strasser (1999) comments, rags were the chief expense manufacturers faced in the production of fine paper products. Rags required extensive processing, but the real problem involved beating and cleaning the rags---a very dusty and, without respiratory protection, unhealthy job. The problem came to a head during a mid-century European cholera epidemic when "the popular acceptance of the germ theory" emerged and "waste itself, and not just its neglect, was implicated in crimes against humanity" (Kennedy, 2007, p. 90). Germs, like invisible biological messages contained in the rags, were being transported overseas, and so the importing of rags across the Atlantic was prohibited.

Germ theory set the postal network concept in a new light: as the symbolic agent of biological correspondences, communicable diseases could spread in the same transport that conveyed trade and literacy transactions. With the content of the mails already serving as a barometer of the moral adroitness and spiritual health of the nation, germ theory introduced a notion of systemic biological threats originating within the system of correspondence and passed on to networked populations. Mail became biologically threatening from invisible toxins embedded within network systems and the material excesses of mass-produced texts. The computer virus, as a form of cybernetic germ transmission, transmutes from this biological threat posed within postal systems.

The demand for paper grew in tandem with popularization of the post and of the alternatives to linen papers, "wood was the most promising," states Strasser (1999, pp. 91-92). This was "thanks to the vast North American forests," and became even more desirable as an alterative when a German wood-pulping invention reached American shores in 1869 . Wood pulp paper was cheap by comparison to parchment and linen. The public perception of paper, that relatively free, dignified technology of the written word, eventually amounted to its being garbage, and this attitude of disposability of the material media of literate culture spread to include even valuable personal correspondence. Strasser states, "in 1857, forty tons of books and papers accumulated by the Bank of the 
United States---including ten tons of autograph letters of leading statesmen, politicians, and financiers---were sold for recycling" (p. 92). Five years later, "Scientific American expressed concern about the number of valuable documents being destroyed for papermaking, but over the next few years thousands of tons of books, newspapers, letters, and business papers were sent to the mills" (p. 93). Once the German wood-pulping technique was established, "by 1885, waste paper was mounting up and becoming a household problem" (pp. 91-92).

\section{Textual Excess and Disposable Discourse}

Mail systems are implicated in the conditions of our literacy environments and the kinds of ethical understandings that are harboured therein. The mass production and transportation of printed texts produces copious waste in the physical environment that is slow to biodegrade (Rathje \& Murphy, 2001). Decaying garbage takes on qualities of impurity that have both a moral and, particularly after the advent of germ theory, biological dimension (Douglas, 1970). Circulars and disposable newsprint provided a discursive model for germ theory. Without treatment, the accumulation of this informational detritus undermined moral certitude, physical health, and social order: "The technological solution to the metaphysical menace of waste was the 'garbage destructor,' later known as the incinerator. Its invention dates back to the $1870 \mathrm{~s}$, making it contemporaneous with the first widespread disposable paper products" (Kennedy, 2007, pp. 90-91)---contemporaneous also with the convocation of the Universal Postal Union and the peak of the nineteenth-century postal culture.

The circumscription of the sovereignty of the individual through the spectacle of mass mailing led mail services toward an increasingly disposable, consumerist orientation. Impersonal postal systems, embodied more by newspapers and advertising than by letters, gave rise to a corresponding impersonality of mail. Over the twentieth century, commercial circulars and impersonal junk mail rose in volume. In the U.S., "the social correspondence of the earlier century gave way, gradually at first, and then explosively, to business mail. By 1963, business mail constituted 80 percent of the total volume" (USPS, 2007). In one hundred years commercialism had taken over this remarkable, motivating force of literacy and private/public discourse. Email may in fact be undergoing a similar cycle, only at a much more rapid pace. It took less than ten years from the widespread adoption of email in the 1990s for the majority of email correspondence to become some type of spam and for information waste management (anti-spam and anti-virus filtering software) to become a high-priority in electronic network systems, as well as a lucrative business (Hedley, 2006).

Electronic mail networks deliver unsolicited junk and spam from unanswerable entities, messages that may also contain computer viruses. Going online, unprotected by often costly security measures, becomes miasmic and dangerous. Cyberspace combines the physical and metaphysical notion of both waste and disposability into an ontological network condition. Kennedy argues "the complete metaphysicality of cyberspace provides the final test case. There, where no physical basis whatsoever grounds beingwith-others, relationships, many between false personas, have the reliability and durability of paper serviettes" (p. 142). The acceptance of disposable discourses feeds into a much broader critical project (Giroux, 2006), in so far as it interpolates the biopolitics of human disposability. Kennedy (2007) states "in the throwaway society, 
disposability has become more than a prevalent feature of commercial goods. It has become...a way of life" (p. 142). With network changes, a fundamental ontological restructuring of relations is at stake. Disposability predominates in electronic mail networks not just conceptually, but in the browsers with trash can symbols, deletion buttons, and so forth. That these features are invaluable for personal information management supports the notion that participating in the network concept today necessitates a constant practice of obliteracy, a perpetual disappearing act in literate relations, a condition of not-having-to-answer-to someone or something.

The ontological dilemma of the writing self is further extended in our relation to automated software, 'netbots' and scripts, which host our literacy transactions whenever we go online, and which write and send most of the email in cyberspace by a very large margin (Zdziarski, 2005). This informational excess is integrated within the mobile systems and literate practices to the point where it seems completely natural, all the while destroying physical environments and endangering virtual environments. Regardless of the size and speed of today's networks, the writer remains un-assured of an audience, at risk of being swallowed by the media torrent (Gitlin, 2002). Before these changes to the network concept occurred, Siegert (1999) claims, "letters were recyclable discourse" (p. 32) feeding the literacy practices of generation after generation. We now offer one another our disposable discourses that float on the surface of the deluge: The fate of postal culture remains with us, even if it's been buried in landfills or bounced back into the ether unanswered.

\section{How It Is and How It Doesn't Have to Be}

How might we counter this pessimistic vision of commercialization and disposability in our many and varied information environments? Is such disposability the inevitable outcome of network growth and capitalist ideology? Is Samuel Beckett's vision in HOW IT IS (1961) necessarily how it is going to be?

So things may change no answer end no answer I may choke no answer sink no answer sully the mud no more no answer the dark no answer trouble the peace no more no answer the silence no answer die no answer. (pp. 146-147)

This vision of the future of the writing self is disturbing because in the midst of communicative affordance, abundance, and automated surveillance, the writing self seems desolate, submitting endless status updates that devolve into numbing redundancy. In an unsigned review in the Times Literary Supplement dated May 21, 1964, an author elaborates on Beckett's literary witnessing of a "different kind of scheme" for the writer, "the author-self recording what is seen by an introspecting self of an infinity of other selves pursuing and cross-examining each other in darkness" (in Graver \& Federman, 1979 , p. 281). The network of digital communications---an infinity of other selves crossexamining each other---lacks a sense of grounding in an answerable ethos or critical understanding for orientation.

In this same picture, we more commonly hear of great promise for the future: wireless devices connecting worlds of likeminded human networks, a social communicator's paradise situated within humanity's dream digital library. This vision is one where everything and everyone is welcome---a worldview instantaneously revealed and revealing. Literacy studies, in turning to the social "real" world of situated practices, 
run the risk of neglecting the robustly autonomous, programmatic, and artificial agency of the network itself and the bots that inhabit its highly encoded, encrypted, and privatized spaces. This agency is a shaper of those lived literacy practices. Such concerns should be basic to the study of mobile literacy.

We are at a point of radical juncture, not at an impasse. As with the physical environment, there are sufficient warning signs that we should be taking seriously the conditions of our information systems and network environments. There is much work presently underway, outside the purview of literacy studies but central to the domain of computing sciences and network developers, to create more efficient systems of technical maintenance and user-friendly affordances for mobile communications. However, with automation of communication systems, we lose sight of actual conditions of the network environment, and the distinction between email and social network sites is a case in point.

Email is the electronic successor to correspondent network practices. Although the relation between email and other network messaging practices is often fluid and polyvalent---alternating between different communications platforms is not uncommon for today's correspondent---the distinction is poignant. Online social networks evolve from historical practices literally connected to the "post," a public location where written messages are left for others, as compared to "mail," which derives from molko, or purse, the top-synched postbag used across Europe and America. Physical posting of messages as a means of correspondence is still practiced in almost every literate social and domestic environment---leaving written messages (on a fridge, putting a note under the door, memos, and so forth) is commonplace.

In the 1970s and 1980s the electronic hosts of newsgroups and Bulletin Board Services (BBS) provided this posting function. Message boards and forums on large digital networks such as USENET were collectively maintained and usually had an administrator who personally oversaw all the posting activity and prevented repeat and multiple posting of a single message. By 2012, this level of personal oversight is utterly impossible given the volume of messages posted to popular social media sites. Moreover, social media corporations and the algorithms on which they operate are private property. When everyone in the global village is coming to a single privately owned post, enormous advertising revenues are generated from free user networks. Now reversed, repeat and multiple (ad) postings are the whole (economic) point from a communications network perspective. What the user saves in money, they pay in consumer attention.

By comparison, email as a social practice is not privately owned and still functions according to post-office-like network protocols. The Internet Service Provider (ISP) makes money through services that usually include a mobile email address, network access, server space, and so forth. The automated ISP usually scans and filters all incoming messages to prevent email network abuses of unsolicited advertising, viral and/or fraudulent email. Owing to sophisticated, artificially intelligent email filters, the success ratio is very high: 98.5 percent, or better, of spam email is identified before it gets to the end user (Zdziarski, 2005). From the user's perspective, automated email doesn't seem to be a problem. Without such automated network allies, however, email would be practically useless. As such, the artificial agent in the user-network relation plays a remarkably important role in the literacies that evolve as a practice of using the electronic post office. From the perspective of the writing self, social networks provide a public space for expression, whereas email still provides a medium of private, personal, 
confessional writing (among its many other purposes). Not infrequently, people do not make this crucial differentiation and post self-disclosing and even incriminating information on social media sites. We might marvel at the lack of good sense and rationalize network literacy as an important educational goal. We might start by asking, "What is to come of the personal and intimate practices of writing for youth learning to write on networks?" The enormous benefits of electronic communications are still only beginning to be experienced the world over, and yet a generation has already grown up on the Internet.

In this paper I have argued that although electronic and physical mail networks have significant differences, they also exhibit some remarkably similar tendencies. Both physical and electronic networks are vulnerable to misappropriation, exploitation, invasive surveillance, loss and theft of private information, and dumping of waste, with potentially long-term effects that undermine - if not poison - the ground of personal sovereignty and answerability in public discourse. The agency of the network and the sovereignty of the networked are increasingly at odds. Information environments, the space in which mobile literacy cultures will grow, are an important, precious, and collectively generated human resource. The maintenance of these environments, and the primary threat to their sustainability, will by and large be the work of programmed agents. For the foreseeable future, correspondence literacies will be formulated in an automated, artificially intelligent context that trans-codes, transmits, and transacts with every message sent. In an age of automated correspondence that expands the possibilities of spontaneous dialogue and creative expression while potentially exposing individuals to many kinds of exploitation, literacy research and scholarship is entrusted with a new and dramatic challenge: To encourage literacy practices that help people around the world gain access to and participate in the riches of the information environment while providing a critical monitoring of the fundamental role the network plays. This must be done so that the new era of mobile literacies and social networks can emerge without over-commercializing and under-valuing the sovereign space of personal, even intimate correspondence and the depth of human relations that these practices make possible.

\section{References}

Aarseth, E. J. (1997). Cybertext: Perspective on ergodic literature. Baltimore, ML: Johns Hopkins University Press.

Allen, M. R. (2003). This is not a hypertext, but...: A set of lexias on textuality [Electronic Version]. ctheory.net. Retrieved June 20, 2007 from http://www.ctheory.net/articles.aspx?id=389

Armstrong, N. (1987). Desire and domestic fiction: A political history of the novel. New York, NY: Oxford University Press.

Bakhtin, M. M. (1990). Art and answerability: Early philosophical essays by M. M. Bakhtin (M. Holoquist, V. Liapunov \& K. Brostrom, Trans.). Austin, TX: University of Texas Press.

Barton, D., \& Hall, N. (Eds.) (2000). Letter writing as a social practice. Philadelphia, PA: John Benjamins Publishing Company.

Beckett, S. (1961). How it is. New York, NY: Grove Press.

Beebee, T. O. (2003). Ancient epistolary fictions: The letter in Greek literature. 
Comparative Literature Studies, 40(3), 329-333.

Bosse, M. J. (1972). Introduction. In The post-man robb'd of his mail or the packet broke open (pp. 5-8). New York, NY: Garland Publishing.

Bourdieu, P. (1984). Distinction: A social critique of the judgement of taste (R. Nice, Trans.). Cambridge, MA: Harvard University Press.

Boureau, A., \& Dauphin, C. (1997). Correspondence: Models of letter-writing from the middle ages to the nineteenth century. Princeton, NJ: Princeton University Press.

Boyer, P. S. (2002). Purity in print: Book censorship in America from the gilded age to the computer age. Madison, WI: University of Wisconsin Press.

Campbell, R. M. (2002). The politics of postal transformation: Modernizing postal systems in the electronic and global world. Montreal and Kingston: McGill-Queens University Press.

Capurro, R. (2006). Toward an ontological foundation of information ethics. Ethics and Information Technology, 8(4), 175-186.

Cook, E. H. (1996). Epistolary bodies: Gender and genre in the eighteenth-century republic of letters. Stanford, CA: Stanford University Press.

Cooke, K. (2007). One hundred years of postal processing in Canada. In J. Willis (Ed.), More than words: Readings in transport, communication and the history of postal communication (pp. 53-70). Gatineau, PQ: Canadian Museum of Civilization Corporation.

Cubitt, S. (2005). Consumer discipline and the work of audiencing. In S. Cohen \& R. L. Rutsky (Eds.), Consumption in an age of information (pp. 79-97). Oxford, UK: Berg.

Dahlberg, L. (2001). The Internet and democratic discourse: Exploring the prospects of online deliberative forums extending the public sphere. Information, Communication \& Society, 4(4), 615-633.

Daunton, M. J. (1985). Royal mail: The post office since 1840. London, UK: The Athlone Press.

Derrida, J. (1978). Writing and difference (A. Bass, Trans.). Chicago, IL: University of Chicago Press.

Dierks, K. (2000). The familiar letter and social refinement in America. In D. Barton \& N. Hall (Eds.), Letter writing as a social practice (pp. 31-41). Philadelphia, PA: John Benjamins Publishing Company.

Douglas, J. Y. (2001). The end of books---or books without end?: Reading interactive narratives. Ann Arbor, MI: University of Michigan Press.

Douglas, M. (1970). Purity and danger: An analysis of the concept of purity and taboo. New York, NY: Penguin.

Fuller, W. E. (2003). Morality and the mail in nineteenth-century America. Chicago, IL: University of Illinois Press.

Gildon, C. (1972). The post-man robb'd of his mail or the packet broke open. London, UK: Garland.

Giroux, H. (2006). Stormy weather: Katrina and the politics of disposability. Boulder, CO: Paradigm.

Gitlin, T. (2002). Media unlimited: How the torrent of images and sounds overwhelms our lives. New York, NY: Henry Holt \& Company.

Graver, L., \& Federman, R. (Eds.) (1979). Samuel Beckett: The critical heritage. New 
York, NY: Routledge.

Hedley, S. (2006). A brief history of spam. Information \& Communications Technology Law, 15(3), 223-238.

Henkin, D. M. (2006). The postal age: The emergence of modern communications in nineteenth-century America. Chicago, IL: The University of Chicago Press.

Hill, R. (1837). Post office reform: Its importance and practicability (2nd ed.). London, UK: Charles Knight.

Himma, K. E. (2007). The concept of information overload: A preliminary step in understanding the nature of a harmful information-related condition. Ethics and Information Technology, 9(4), 259-272.

Hôflich, J. R., \& Gebhardt, J. (2005). Changing cultures of written communication: Letter---e-mail---SMS. In R. Harper, L. Palen \& A. Taylor (Eds.), The inside text: Sacred, cultural and design perspectives (pp. 9-32). Netherlands, EU: Springer.

IDC. (2007). The Expanding. Digital universe: An IDC White Paper - sponsored by EMC. A Forecast of Worldwide. Information Growth Through 2010. Retrieved March 25, 2008, from http://www.emc.com/collateral/analyst-reports/expandingdigital-idc-white-paper.pdf.

John, R. (1995). Spreading the news: The American postal system from Franklin to Morse. Cambridge, MA: Harvard University Press.

Kennedy, G. (2007). An ontology of trash: The disposable and its problematic nature. Albany, NY: State University of New York Press.

Kielbowicz, R. B. (1989). News in the mail: The press, post office, and public information, 1700-1860s. New York, NY: Greenwood Press.

Kielbowicz, R. B. (2007). Testing the boundaries of postal enterprise in the U.S. freemarket economy 1880-1920. In J. Willis (Ed.), More than words: Readings in transport, communication and the history of postal communication (pp. 85-100). Gatineau, PQ: Mercury Press.

Krug, G. (2005). Communication, technology and cultural change. Thousand Oaks, CA: Sage.

Landow, G. P. (1997). Hypertext: The convergence of contemporary critical theory and technology. Baltimore, ML: The Johns Hopkins University Press.

Locke, J. L. (1998). Why we don't talk to each other anymore: The de-voicing of society: How email, voice mail, the Internet, and technomania are making us into a society of strangers, New York, NY: Simon \& Schuster.

Lyons, M. (1999). Love letters and writing practices: On ecritures intimes in the nineteenth century. Journal of Family History, 24(2), 232-239.

McLuhan, M., Fiore, Q., \& Agel, J. (1967). The medium is the massage: An inventory of effects. New York, NY: Bantam Books.

Milne, E. (2002). The epistolary body of email: Presence, disembodiment and the sublime. Southern Review: Communication, Politics \& Culture, 35(3), 80-93.

Milne, E. (2003). Email and epistolary technologies: Presence, intimacy, disembodiment. Fiberculture, 2(2), 1-14.

Nielsen, G. M. (2002). The norms of answerability: Social theory between Bakhtin and Habermas. Albany, NY: State University of New York Press.

Noam, E. M. (1987). The public telecommunications network: A concept in transition. The Journal of Communication, 37(1), 30-48. 
Poster, M. (1990). The mode of information: Poststructuralism and social context. Cambridge, UK: Polity Press.

Price, B. (1942). Governmental censorship in war-time. The American Political Science Review, 36(5), 837-849.

Prinsloo, M. (2005). The new literacies as placed resources. Perspectives in Education, 23(4), 87-98.

Rathje, W., \& Murphy, C. (2001). Rubbish!: The archeology of garbage. Tucson, AZ: University of Arizona Press.

Richardson, S. (1740/1816). Pamela: or virtue rewarded: In a series of familiar letters from a beautiful young damsel to her parents. London, UK: T. Kinnersley.

Rosenblatt, L.M. (2004). The transactional theory of reading and writing. In R.B. Ruddell, \& N.J. Unrau (Eds.), Theoretical models and processes of reading (pp. 1363-1398). Newark, DE: International Reading Association.

Sale, W. M. (1950). Samuel Richardson: Master printer. Ithaca, NY: Cornell University Press.

Seltzer, M. (2000). The postal unconscious. The Henry James Review, 21(3), 197-206.

Shuttleton, D. E. (1999). "Pamela's library": Samuel Richardson and Dr. Cheyne's "universal cure". Eighteenth Century Life, 23(1), 58-79.

Siegert, B. (1999). Relays: Literature as an epoch of the postal system (K. Repp, Trans.). Stanford, CA: Stanford University Press.

Spinello, R. A. (1999). Ethical reflections on the problem of spam. Ethics and Information Technology, 1(3), 185-191.

Spinello, R. A. (2001). Code and moral values in cyberspace. Ethics and Information Technology, 3(2), 137-150.

Strasser, S. (1999). Waste and want. New York, NY: Henry Holt and Company.

Tate, A. (1994). Bakhtin, addressivity, and the poetics of objectivity. In R. D. Sell \& P. Verdonk (Eds.), Literature and the new interdisciplinarity: Poetics, linguistics, history (pp. 135-150). Atlanta, GA: Rodopi.

Universal Postal Union. (2003). The role of postal services in shaping the information society. Paper presented at the World Summit on the Information Society (WSIS), Geneva 2003 and Tunis 2005. Retrieved March 25, 2008, from https://docs.google.com/viewer?a=v\&q=cache:yM1Hsdfm98UJ:www.itu.int/dms _pub/itu-s/md/03/wsispc2/c/S03-WSISPC2-C-0090!!PDF-

E.pdf+\&hl=en\&pid=bl\&srcid=ADGEEShRzeHJni4SX3ydYfO0kgIxXZka_tOkt

WeOIV nqAPUYIPSQ7GNHymmZBdgIvARvXToeoPfXh-

IJ0MCDbAewQ1YOX1QYU9O758w0YQctXTerQjpZ-

b1hUegAXCHd0LCqH63ZTm0\&sig=AHIEtbSm-

yqoD0isOaYD0RX4Q43hWkVLxQ\&pli=1

USPS. (2007). History of the U.S. Postal Service. Retrieved December 7, 2007, from http://about.usps.com/publications/pub100/pub100_001.htm

Veidemanis, G. V. (1982). The humane art, English teachers, and the postal service. English Journal, 71(5), 60-63.

Yates, S. J. (2000). Computer-mediated communication: The future of the letter? In D. Barton \& N. Hall (Eds.), Letter writing as a social practice (pp. 233-251). Philadelphia, PA: John Benjamins Publishing Company.

Zdziarski, J. A. (2005). Ending spam: Bayesian content filtering and the art of statistical 
language classification. San Francisco, CA: No Starch Press.

Author Biography

Kedrick James is a writer, teacher, and arts-based researcher specializing in secondary English curriculum and teacher education. Through his literary pursuits, which include collaborations with musicians, video artists, visual artists, poets and programmers, he is continually prodding the pedagogical possibilities of creative living, teaching, and research. His research interests focus on information environments, cultural recycling, language automation, and assessment of written English. He is an instructor at the University of British Columbia, Department of Language and Literacy Education.

\section{Endnotes}

i Included in the publication is The Lover's Sighs, which Bosse (1972) calls "an important early effort to use letters for dramatic story telling" (p. 8). Noteworthy for its use of different writing styles to personalize fictional characters, the narrative concerns two mistresses of King Alphonso---the jilted ex-consort Stremunia seeking his attention has her mail intercepted by the deceitful current one, who responds in the King's stead, and the intended dialogical contact remains unconsummated.

ii In his introduction, Richardson (1740) claims to be the "editor" of a true correspondence between a young woman seeking advice from her father in order to ward off the attentions of a rakish, wealthy suitor---she succeeds and the suitor is only able to symbolically violate her chastity by opening and reading her personal letters. The enclosure of the letter within folds of paper and a sealed envelope added potency to the gendered metaphor (Siegert, 1999) that was not lost on the reading public. The letter's symbolic properties shaped both literary production and social perception of postal practices.

iii As Kielbowicz (1989) and John (1995) explain, the bulk of mail deliveries were not letters, but rather newspapers. Newspapers had reduced rates and some traveled free of cost, fueled by the need for daily trade and business information, more than for politics or entertainment.

iv Similarly, ads for Viagra and other pharmacological products are the most common type of unsolicited electronic mail. 